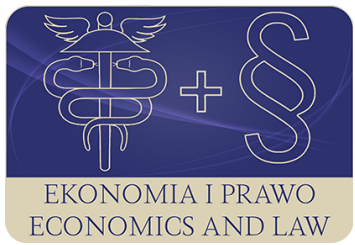

ECONOMICS AND LAW
EKONOMIA I PRAWO. ECONOMICS AND LAW

Volume 16, Issue 3, September 2017

p-ISSN 1898-2255, e-ISSN 2392-1625

www.economicsandlaw.pl

ORIGINAL ARTICLE

received 13.06.2017; revised 16.09.2017; accepted 30.09.2017

Citation: Skrodzka, V. (2017). Tax neutrality at leasing or rural farms. Ekonomia i Prawo. Ecomomics and Law, 16(3): 343-353. doi:10.12775/EiP.2017.024.

\title{
Tax neutrality at leasing or rural farms
}

\section{VIOLETTA SKRODZKA}

Gdynia Maritime University, Faculty of Entrepreneurship and Quality Science, Department of Economics and Economic Policy, ul. Morska 81-87, 81-225 Gdynia, Poland

■v.skrodzkar@wpit.am.gdynia.pl

\begin{abstract}
Motivation: One of the forms of investing by individuals is real estate. The scope of the quoted content including properties in the form of agricultural land. Until May 1, 2016, any individual could become the owner of agricultural land in Poland. The free purchase of agricultural land was limited by the restrictive provisions of Act on shaping the agricultural system (2003) of April 11, 2003. The change of regulations concerning the free trade of agricultural properties did not result (although it tends to do) in the fact that agricultural land remain only in the hands of farmers. Individuals who have acquired land before May, 2016 and are not related to agriculture can lease or rent the land to others. The received rent is a financial advantage that is treated in a special way by the tax law. The benefits obtained by leasing by a natural person not related to agriculture are treated as personal income tax on a preferential basis.

Aim: The purpose of this article is to analyze the taxation of income earned by leasing or renting agricultural properties to third parties.

Results: The remuneration received from a lease of a farm or its components for agricultural purposes is not a source of income in terms of personal income tax. Revenues earned from renting or leasing properties to third parties for non-agricultural purposes are subject to personal income tax. In this case, the rent received is a source of personal income and must be reported to the appropriate tax office.
\end{abstract}

Keywords: lease; farm; agricultural activity; income tax on leased agricultural land for agricultural and non-agricultural purposes; Poland

JEL: K11; K12; K34; Q100; Q150 


\section{Introduction}

Paid access to property assets is one of the form of earning .Properties are both a form of investing by individuals as well as a frequent subject of tenancy agreement or lease. These contracts, which generate income, are subject of personal income tax. The aim of this article is to analyse the legal regulations related to the lease of agricultural holdings in the context of personal income tax.

Another, but not less important, objective is to compare existing taxation rules of income from the provision of agricultural holdings and other properties. The inspiration for writing this article is the conviction that in the present reality there is no basis for preferential taxation of income from the lease of a farm for agricultural purposes. Existing privileges for non-agricultural land owners deny the principle of equality of taxation ${ }^{1}$ formulated Smith (1954, p. 584), or derived from the idea of equality principle of justice (Gomulowicz \& Malecki, 1995, p. 44) $)^{2}$.

\section{Renting a farm}

Leasing of rural farms has been discussed only in Poland but also in other countries (Duffy, 2014, pp. 21-26; McEowen, 2015; Tidgren, 2017; Gaffney, 1992). Sharing ownership of land with others in exchange for a fee was already known (in Poland) in the feudal system. It was the peasants who were obliged to use non-owned land in exchange for a feudal pension. At present, the transfer of ownership is defined by the rental or lease agreements. Both of them give the right to use the property of a third party. Most people looking through the prism of customary duties equate the two agreements. Although both of them are placed in the same title XVII of the cited legal act, not without reason separate sections are devoted to them. The fundamental difference between a leasing and renting, which is directly derived from the definition, is the retrieval of benefits. Only a leaseholder is entitled to benefit, not a tenant. Typically, the subject of rental are cars, commercial premises, apartments, rooms and machines. However, agricultural land, plots, allotments, company and patent rights are leased. Getting benefits is the right, not the obligation of the lessee. The tenant has the opportunity to receive benefits in the form of agricultural produce, income from running a business or gardening. A summary of the characteristics of the two contracts is presented in the table 1.

1 The author states 'The subjects of every state ought to contribute towards the support of the Government, as nearly as possible, in proportion to their respective abilities, that is, in proportion to their revenue which they respectively enjoy under the protection of the State'.

2 The content of this rule recommends that the tax system: (a) does not contain tax exempt privileges for classes, classes and social groups; (b) make it impossible to evade the obligation to pay tax. 
For lease of premises and lease of agricultural land in the Civil Code (1964) there are additional clarifications. For rent the elucidations cover most of the rights and obligations of the tenant of the premises. For lease of agricultural land, the regulation includes:

- term of notice in the absence of provisions in the contract;

- compensation for the sown seed;

- rent-free usage of agricultural land.

According to the last survey conducted in 2010 by the General Agricultural Census, the Polish area of farms in covers 18,069.8 thousand ha. In the hands of the private sector where the vast majority are individual farms there were $95.6 \%$ of the land, while the public sector held $4.4 \%$ of total land area. The area of agricultural land covering 15503 thousand ha was owned by 2,264.7 thousand farms, which accounted for $99.4 \%$ of all farms. The last data published by Central Statistical Office in 2010 indicate that in Poland there were 702.1 thousand agricultural holdings of up to lha, and 1562.6 thousand with more than 1 ha (GUS, 2011, pp. 29-30).

In Poland exists no data for the surface of leased land. Such information is not provided by the Statistical Yearbook of Agriculture and Eurostat. Data on leased land are also recorded by the Agency for Restructuring and Modernization of Agriculture. Here, farmers applying for payment give the area of land used without the differentiation of ownership and rent. Difficulties in collecting information on leased agricultural land increase the one year lease periods and the possibility of concluding oral agreements between neighbours.

\section{Neutrality of farm lease}

Tax regulations do not include the notion of tax neutrality. Such terms do not exist in the general tax legislation, the Tax Ordinance, or specific tax laws. This position seems to be appropriate, because there is another purpose for legal regulations. Lawyers and economists attribute tax neutrality to fiscal system and to taxation, but they treat it like a postulate. Tax neutrality is not attributed to a specific tax, although it may be reflected in legal solutions. This is the case with value added tax, although the existence of the tax itself denies the existence of neutrality. In reference to income tax neutrality should be regarded as a colloquial term. Although the question of taxation is a typical legal issue, the definition of neutrality for the developed content is assumed to be indifferent and having no impact. The concept of neutrality is not homogeneous. There are internal and external, legal and economic neutralites, etc. overview of the different aspects of neutrality is presented by Gibasiewicz (2012, pp. 48-58). This study assumes that rent from holding of a farm or its components for agricultural purposes remains tax neutral. The income earned by the lessor does not have any effect on personal income tax.

According to Kosikowski (2003, p. 466) so-called the neutrality of public revenues, and especially taxes, was created by the liberals. 
They considered that any state intervention in human behaviour is detrimental to the rights and natural liberties or disrupts the economy based on objective economic laws. The quoted author describing the assumptions of the liberals stated that the neutrality of public revenue is unnecessary and public finances, while being an effective instrument for influencing human behaviour fulfill the functions of the state. The public revenue system should be created with full awareness of the objectives and effects, while ensuring fairness and efficiency. It should not be accidental and focused solely on achieving ad hoc goals without taking into account side effects.

Here comes the question about the taxation of rent from lease of a farm or its part for agricultural purposes. What purpose did the legislator impose that no tax is levied on such income? Is a situation when there is a tax on the availability of any other asset fair? Has this system became irrelevant in the current reality? The answer should be sought by analyzing the socio-economic changes that took place in Poland after 1989.

Analyzing the changes taking place in the Polish countryside as a result of the changes taking place in the whole Polish economy, three periods can be distinguished in leases of agricultural holdings.

The first period is renting of agricultural land by a farmer to another farmer. These leases were carried out under the conditions of economic and demographic changes. Individual agriculture that dominated in Poland was experiencing shortages as to the abundance of adequate funds, and thus agricultural equipment. The agricultural market emerged new opportunities to buy land after liquidated state farms. Farmers did not receive any subsidies at this time, and the State intervention concerned preferential loans which financed, among others purchase of land. Sharing the land by a farmer with another farmer in return for a fee could be treated as compensation for the benefits gained from farming. For a farmer who did not have the opportunity to do farming, the rent he received was as if he it was a farm income. For a farmer who had no possibility of agricultural activity obtained lease fee was like income from agricultural activities. Under the conditions of such leases the lack of income tax on the salary received did not raise any doubts.

The second period should be closely linked to specific social security regulations. Small areas of agricultural land acquisition by way of purchase by farmers was connected with avoiding payment of contributions to the Social Insurance Institution. Farmers' social insurance provided by the Agricultural Social Insurance Fund has been and still is lower than the payments paid to Social Security. These land was often rented to local farmers free of charge or for a nominal amount. Furthermore, these oral lease agreements were not recorded in the register of land and buildings so no income tax was levied on rent.

The third period is observed after Poland's accession to the European Union. The high EU benefits that could be obtained by the owners of agricultural land encouraged people who did not show any connection with agricultural activities to purchase land. Some of the land, after meeting the administrative require- 
ments, was allocated to forestation, thus acquiring the right to an EU subsidy for twenty years. Some of the land was left in accordance with its intended purpose, but tenants were authorized to use it. Owners of large areas of leased land receive income in the form of rent. Nowadays, this amount is not small. In media announcements this is, at least, the amount of the EU subsidy.

Since May 2016 there is no possibility of buying farmland by non farmer. The Agricultural Law Act imposes strict conditions to buyers of agricultural land. This restriction does not eliminate the leases of these lands, which were acquired previously by non farmers. While in the first and second stages mentioned above, the lack of rental income tax could reasonably be justified, at present these arguments cannot.

\section{Legal regulation of taxation on farm lease}

According to the Personal Income Tax Act (1991), all types of income are subject to taxation, except for income that is not listed as exempt or are exempted under the Tax Ordinance. In the aforementioned law, there are two regulations concerning the lease of a farm. The first record is article $2 \mathrm{sec} .1$ point 1 . It concerns the exclusion of the application of the provisions of the Act to income from agricultural activity except for income from special departments of agricultural production. This record reflects logical consistency of the existing tax system.

Agricultural activity and therefore the benefits of farming it, are subject to agricultural taxation. Hence, part of the income from agricultural activity on land expressed in hectares is transferred to an entity equipped with an attribute of public authority.

The second entry is article 10, paragraph. 1, point 6 and refers to sources of income. The legislator stated that sources of income are, inter alia, 'rent, sublease, lease, sublease and other similar agreements, including the lease or subleasing of special sections of agricultural production, of agricultural holdings or of their constituents for non-agricultural purposes, or for the administration of special agricultural production units, except for the assets related to economic activity' (Personal Income Tax Act, 1991). The record has existed since the beginning of the Personal Income Tax Act (1991), i.e., January 1, 1992. The only modification introduced is the addition of words, point. 6 'except for the assets related to economic activity'. It was introduced in 2000 and have been in force since 1 January 2001 (Act Amending the Personal Income Tax Act and amending certain acts, 2000). Both the Announcement by the Speaker of the Sejm of the Republic of Poland (2016) of 7 December 2016 and the Act in the annex to the notice indicate that in 2017 the content of the record has not change.

The decisive factor for income tax on rent received from lease of land is ,thus, the concept of agricultural activity and the notion of farm. The legislator in the aforementioned Act precisely defined the agricultural activity. As defined in Art. 2 sec. 2 agricultural activity 'is an activity involving the production of plant or animal products in the unprocessed state (natural) from their 
own crop or husbandry or breeding, including the production of seed, nursery, breeding and reproductive material, vegetable gardening, greenhouse and growing under the foil, the production of ornamental plants, cultivated mushrooms and orchard, breeding and production of embryonic material of animals, birds and insects, industrial-farm type livestock production and fish farming, as well as activities where the minimum periods of retention of purchased animals and plants during their biological growth are at least:

- a month - in the case of plants,

- 16 days - in the case of geeor ducks highly specialized intensive fattening,

- 6 weeks - for other slaughtered poultry,

- 2 months - for other animals - counting from the date of purchase' (Personal Income Tax Act, 1991).

The characteristic feature of agricultural activity is the production of products from cultivation, rearing or farming in the unprocessed state. The cited content is more specific to the definition of agricultural activities included in the Agricultural Tax Act (1984) and the Farmers' Insurance Act. The catalog of components included in the scope of agricultural activity determines at the same time: - whether you are an income tax payer running an agricultural business;

- whether you are an income taxpayer receiving a rent from a farm or agricultural holdings.

Income indirectly related to agricultural activity or arising from agricultural activity is taxed as personal income tax. The revenues obtained do not constitute agricultural revenue and are therefore not included in the taxable income.

The second term for the qualification of incomes from personal income tax is the farm. Here the legislator refers to the definition concerning Agricultural Tax Act (1984). An agricultural area is considered to be a farm of a total area exceeding 1 ha or 1 ha of conversion, owned or held by a natural person, legal entity or organizational unit, including a company without legal personality. Land forming a farm is the subject of agricultural taxation and is classified in the land and buildings records as agricultural land or as tree-lined or bushlined land on arable land, except for land used for business activities other than agricultural activities (Agricultural Tax Act, 1984). For example, 0.8 hectares of IIIa plots located in the fourth district or slightly over half a hectare of class I in the first tax district forms 1 hectare of land. Land conversion is detailed in the agricultural tax law, while the allocation of land to one of the four tax districts is in the Regulation of the Minister of Finance (2010) of 10 December 2001 on the classification of municipalities and cities into one of the four tax districts.

The amounts received by landowners of the leased land raise uncertainty. The Tax Chamber's director in Warsaw dismissed the doubts concerning taxation by acting on behalf of the Minister of Finance in an Individual interpretation (2010). He states that if a farm is leased to an agricultural activity referred to the mentioned above article $2 \mathrm{sec}$. Section 2 of the Personal Income Tax Act (1991), the income earned by the lessee does not constitute a source of income 
for the purposes of personal income tax. The legal status of the discussed issue has not changed since the date of this interpretation. Thus, the rent levied on a farm for agricultural activity for many people remains neutral to taxation.

\section{Taxation of income on the lease of a farm for agricultural and non-agricultural purposes}

As evidenced by the regulation cited above, with regard to renting, subletting, leasing and subleasing services include, among others, the lease of a farm for non-agricultural purposes or for the management of special agricultural production. Leasing a farm or its components for agricultural purposes is not, however, a source of income within the meaning of the Personal Income Tax Act (1991). In order to recognize the lease of a farm or its components as a source of income the most important is to know their purpose of usage.

The definition of a farm includes in its components only the land taxed by agricultural tax. Therefore, only some of natural person income from leasing, subleasing of a farm or farmland components are excluded from personal income tax. This applies only to income from lease and sublease of the whole farm i.e., the whole of the land included to it, being the subject of agricultural taxation, as well as rental income.

The land classified as wasteland, land on which the business is carried out, land under farm buildings, and buildings belonging to the farm are not excluded from taxation.

The legal status presented above states that only the lease of agricultural land for agricultural activity is not an object of personal income tax. The lease of a farm, understood only as a land and its components for non-agricultural purposes, is a source of natural persons income taxation. The above cited article 10, item 6. explicitly specifies it. The lease of a farm or its components for non-agricultural purposes or running special branches of agricultural production is the subject of personal income tax.

In addition to agricultural land, farms include other properties and assets, that can be leased to interested parties. There are farm buildings and agricultural equipment that can serve both agricultural and business purposes. Irrespective of their allocation, the amounts obtained from their leasing are the subject of taxation.

\section{Methods}

This paper analyse the Polish legal regulations concerning taxation of income generated from lease of agricultural holdings. A simulation is compiled to compare the effects of the adopted legal solutions, using comparative analysis and deduction. The simulation included three properties, i.e., a farm leased for agricultural purposes, a farm leased for non-agricultural purposes and a leased 
residental property comparable in value. The comparison criterion is the value of cash after tax at the disposal of the lessor.

\section{Simulation of rents from agricultural land and residential property lease}

Two properties have been selected for the simulation, i.e., a farm meeting the conditions set forth in Agricultural Tax Act (1984) and a residential property. The properties information was obtained on the basis of a personal interview with the properties owners. The farm was purchased for investment purposes in 2011-12 for PLN 135 000. It covers 62885 hectares of conversion, which represents only 1,1507 hectares of conversion due to poor quality of agricultural land. The second property is an apartment located in a nearby town. It was purchased for rent for PLN 140000 in 2012. The apartment did not require any financial investment. Both properties are located in the north-western part of the Podlaskie Voivodship where multi-family housing develops very slowly, and demand for land by local farmers is high. The region belongs to typically Polish agricultural areas.

Both properties are owned by two individuals. The first of them was leased out and the lease fee was PLN 6200 per year. According to the agreement, the leased area is intended for agricultural activities. The parties to the agreement obliged the tenant to pay agricultural taxes and other burdens associated with agricultural activity on the property. The residential property is the subject of the lease agreement. The monthly rent to the landlord is PLN 500 per month. In this case, the tenant was also obliged to pay real estate tax and any fees related to the apartment. The financial effects of paid access to real estate including income tax are presented in table 2.

The amounts paid to the owners of the properties are comparable on a yearly basis and amount to PLN 6200 and PLN 6 000, respectively. In the case of farmland, the amount received from the lessee remains entirely at the disposal of the owner. In the case of residential property, the received rent is reduced by income tax. When choosing flat-rate forms of taxation, the amount that has to be paid to the Tax Office is PLN 510, this means that the owner of the apartment has the amount of PLN 5 490. Choosing general principles of taxation, he is obliged to pay a tax of PLN 1080 . In this case, the income of the apartment owner after the deduction of tax is the amount of PLN $4920^{3}$. If the farmland was leased to non-agricultural purposes then taxation would be adequate to the rules shown above for the apartment.

The quoted amounts for this particular examples indicate differences between the benefits achieved by different properties owners. They do not reflect

${ }^{3}$ Flat-rate income tax is $8.5 \%$ for apartments that are not rented seasonally. According to personal interview, the current market price of agricultural property is 300,000 PLN, while the price of residential property has not changed since the time of purchase. However, this value should be regarded as accrued but unrealized until the sale. 
the scale of the phenomenon due to the lack of data on leased agricultural land. As a result, it is difficult to quantify the amount of money that could generate public revenues. The privileged status of owners of agricultural land transferred for remuneration for agricultural activity is not publicly-available.

\section{Conclusion}

If the farm defined in the agricultural tax is leased for an agricultural activity as defined in the Personal Income Tax Act (1991), the income earned by the landlord is not taxable. Media and disclosed financial interests indicate that large areas of agricultural land are owned by people whose functions do not indicate agricultural activity. The same applies to citizens who long time ago moved out of the Polish countryside and possess agricultural land acquired by way of inheritance, donation or purchase.

When traveling in Poland it is difficult to find land lying fallow in the spring and summer for most regions. This means that the land is leased to farmers in exchange for rent. It also means the absence of income tax on such revenue. The existing state could be reduced by introducing either the definition of a farm or the term 'farmer' in the definition of agricultural activity.

By introducing either the definition of a farm, or a word 'farmer' into the definition of agricultural activity, the existing state could be limited. The definition of a farmer is neither included in agricultural tax nor even in the personal income tax. It is included in the Act on shaping the agricultural system (2003) of April 11, 2003, but the existing rules of income taxation do not refer to it. Introducing changes to the tax rules would result in uniform principles of taxation of income from rental of all properties.

\section{References}

Duffy, M. (2014). Farmland Ownership and Tenure in lowa 2012. Ames: Lowa State University.

Gaffney, M. (1992). Rising inequality and falling property tax rate. Retrieved 05.09.2016 from http://savingcommunities.org.

Gibasiewicz, D. (2012). Zasada neutralności podatku od wartości dodanej w orzecznictwie Trybunatu Sprawiedliwości Unii Europejskiej. Warszawa: Wolters Kluwer.

Gomułowicz, A., \& Małecki, J.(1995). Podatki i prawo podatkowe dla studentów i praktyków. Poznań: Ars boni et aequi.

GUS. (2011). Użytkowanie gruntów. Powszechny Spis Rolny 2010. Retrieved 09.09.2016 from http://stat.gov.pl.

Interpretacja indywidualna $\mathrm{z}$ dnia 02.12.2010 r. [Individual interpretation issued on 02.12.2010] (IPPB1/415-834/10-2/JB) (Poland). 
Kosikowski, C. (2003). Pojęcie, funkcje, rodzaje dochodów publicznych. In C. Kosikowski, \& E. Ruśkowski (Eds.), Finanse publiczne i prawo finansowe. Warszawa: ABC.

McEowen, R.A. (2015). Iowa farm leases - legal, economic, and tax consideration. Retrieved 05.09.2016 from https://www.calt.iastate.edu.

Obwieszczenie Marszałka Sejmu Rzeczypospolitej Polskiej z dnia 7 grudnia 2016 r. w sprawie ogłoszenia jednolitego tekstu ustawy o podatku dochodowym od osób fizycznych [Announcement by the Speaker of the Sejm of the Republic of Poland on 7 December 2016 about the publication of the uniform text of the Personal Income Tax Act] (Dz.U. 2016 poz. 2032) (Poland).

Rozporządzenie Ministra Finansów z 10 grudnia 2001 w sprawie zaliczenia gmin oraz miast do jednego z czterech okręgów podatkowych [Regulation of the Minister of Finance of 10 December 2001 on the classification of municipalities and cities into one of the four tax districts] (Dz.U. $2001 \mathrm{nr} 143$ poz. 1614) (Poland).

Smith, A. (1954). Badania nad naturą i przyczynami bogactwa narodów. Warszawa: PWN.

Tidgren, K.A. (2017). Tax implications of a farmland lease. Retrieved 09.09.2016 from https://www.calt.iastate.edu.

Ustawa z 11 kwietnia 2003 r. o kształtowaniu ustroju rolnego [Act on shaping the agricultural system of April 1l, 2003] (Dz.U. $2016 \mathrm{nr} 0$ poz. 2052) (Poland).

Ustawa z 9 listopada 2000r. o zmianie ustawy o podatku dochodowym od osób fizycznych oraz zmianie niektórych ustaw [Act Amending the Personal Income Tax Act and amending certain acts of 9 November 2000] (Dz.U. 2000 nr 104 poz. 1104) (Poland).

Ustawa z dnia 15 listopada 1984 r. o podatku rolnym [Agricultural Tax Act of 15 November, 1984] (Dz.U. 2016 poz. 617) (Poland).

Ustawa z dnia 23 kwietnia 1964 Kodeks cywilny [Civil Code Act of April 23, 1964] (Dz.U. 2017 poz. 459) (Poland).

Ustawa z dnia 26 lipca 1991 r. o podatku dochodowym od osób fizycznych [Personal Income Tax Act of of 26 July 1991] (Dz.U. 2016 poz. 2032) (Poland).

\section{Acknowledgements}

Author contributions: author has given an approval to the final version of the article.

Funding: this research was fully funded by the Gdynia Maritime University.

Note: the results of this study were presented at 9th International Conference on Applied Economics Contemporary issues in Economy (June 22-23, Torun, Poland). 


\section{Appendix}

Table 1.

Lease and tenancy with the right to collect profits agreements

\begin{tabular}{|c|c|c|}
\hline Specification & Lease agreement & $\begin{array}{l}\text { Tenancy with the right to collect } \\
\text { profits agreement }\end{array}$ \\
\hline Form & $\begin{array}{l}\text { Oral or written, but for properties } \\
\text { and premises rented for more than } \\
\text { a year is required in writing. The } \\
\text { absence of this form means indefi- } \\
\text { nite time. }\end{array}$ & $\begin{array}{l}\text { Oral or written, but for the subject } \\
\text { of lease for more than one year is } \\
\text { required written form. The absence } \\
\text { of this form means indefinite time. }\end{array}$ \\
\hline Form & $\begin{array}{c}\text { The law determines the subject } \\
\text { of the contract as an object. It may } \\
\text { be movable or immovable property } \\
\text { as well as their constituent parts that } \\
\text { serve the intended purpose. }\end{array}$ & $\begin{array}{c}\text { The law determines the subject } \\
\text { of the contract as an object. It may } \\
\text { be movable property, real estate } \\
\text { as well as usage rights from which } \\
\text { benefits can be achieved. }\end{array}$ \\
\hline Purpose of the agreement & $\begin{array}{c}\text { The mere usage of other people's } \\
\text { property, which does not provide } \\
\text { benefits }\end{array}$ & $\begin{array}{l}\text { Both the usage of someone else's } \\
\text { property and the right to reap } \\
\text { benefits from it }\end{array}$ \\
\hline The possibility of further sharing & $\begin{array}{c}\text { In the absence of objections arising } \\
\text { from the contract the subject } \\
\text { of the contract can be given free } \\
\text { of charge or sublet. This does not } \\
\text { apply to premises or parts thereof. } \\
\text { Here the consent of the landlord is } \\
\text { required }\end{array}$ & $\begin{array}{l}\text { Object of the lease may not be } \\
\text { forwarded free of charge and sublet } \\
\text { to a third party without the consent } \\
\text { of the lessor }\end{array}$ \\
\hline Liability & $\begin{array}{l}\text { The leaseholder is responsible for } \\
\text { maintaining the rental property } \\
\text { in its intended condition }\end{array}$ & $\begin{array}{l}\text { The lessee is responsible for } \\
\text { maintaining the subject of the lease } \\
\text { in a non-deteriorated condition }\end{array}$ \\
\hline $\begin{array}{l}\text { Payment of rent Contract period af- } \\
\text { ter which it is recognized for a time } \\
\text { not marked } 10 \text { years } 30 \text { years }\end{array}$ & Rent paid in advance & Rent paid in arrears \\
\hline $\begin{array}{l}\text { Contract period after which time is } \\
\text { recognized as not marked }\end{array}$ & $\begin{array}{l}\text { Contract period after which time is } \\
\text { recognized as not marked }\end{array}$ & 30 years \\
\hline
\end{tabular}

Source: Own preparation based on Civil Code (1964).

Table 2.

Amount remaining at owner's disposal (in PLN)

\begin{tabular}{lccc}
\hline \multicolumn{1}{c}{ Specication } & $\begin{array}{c}\text { Renting an apartment } \\
\text { taxed on a flat rate basis }\end{array}$ & $\begin{array}{c}\text { Renting an apartment } \\
\text { taxed on general terms }\end{array}$ & $\begin{array}{c}\text { Farm intended for agri- } \\
\text { cultural purposes }\end{array}$ \\
\hline Amount of payment & 6000 & 6000 & 6200 \\
Tax & 510 & 1080 & - \\
Income after deduction of tax & 5490 & 4920 & 6200 \\
\hline
\end{tabular}

Source: Own preparation. 
